\title{
GA による送配電系統の電力損失最小化手法
}

\author{
正員青 木 秀 憲 (東海大) \\ 正員水谷芳史(東海大)
}

Implementation of Genetic Algorithm for Transmission and

Distribution Loss Minimum Method

Hidenori Aoki, Member, Yoshibumi Mizutani, Member (Tokai University)

キーワード : 遺伝アルゴリズム, 送配電, 電力損失, コンデンサ, 変圧器

\section{1. まえがき}

送配電系統では, 電力損失を軽減し多くの電力を輸送す るためにコンデンサ $C_{j}$ で力率改善を図ったり,タップ切 換変圧器 $T_{k}$ (基準変圧器からの倍率 $n_{k}$ )で電圧を規定值 に保つ自動化が可能となってきた。これらの最適化を図る ために, 遺伝的アルゴリズム (GA)を用いた有効な手法が 文献 (1)で提案されている。しかし, 奏運用を考慮した 際, 最適值に機器を同時に切り換えることは困難であり, 設定過程での時間的ずれによって電圧が規定值から大きく 外れたり, 自動運転時に一部が最適值に設定できないと き，GAを用いた手法でこれに対処する方法は開発されて いない。

そこで本レターでは, まず世代当たり有限值 $\left(m_{1}\right.$ 個)の 設定值変更を条件にもち, 電圧を規定範囲に保ちながら最 適值に切り換えるGA を提案する。次に, 一般に送配電 系統では同時にすべての機器を切り換えられないことを考 慮して, 提案したGAにおいて機器 1 台ずつ切り換える ものとして $m_{1}=1$ と置き, GAの世代の動きを設定值切 換えの手順として取り扱う, 新しい電力損失軽減対策手法 として用いる(2)。

\section{2. 提案手法}

有限個の設定值変更を条件にもつ本 GAでは， $C_{j}, n_{k}$ の計 $m_{0}$ 個に対して, 個々に 2 進数で表現された遺伝子 （以下, 部分遺伝子と呼ぶ） $m_{0}$ 個の初期運転状態の個体を 構成する。そして, 初期生物集団発生や交差における遺伝 子操作の際に, 各 $C_{j}, n_{k}$ に対応する $m_{1}$ 個以内の部分遺 伝子ごとに入れ換える操作を実施する。すなわち，1回当 たり $m_{1}$ 個の部分遺伝子の操作ができるという条件を考慮 した本 GA の計算手順は次のようになる。

（1） $C_{j}, n_{k}$ の範囲と精度の選定 $\quad C_{j}, n_{k}$ の各可変 籁囲を例えば 16 等分して 2 進数 4 ビットで各部分遺伝子 を作り，これにより初期運転状態の個体 $I(0)$ を表現する。

(2) 適応度の選定適応度 $f\left(I_{i}\right)$ は母線電圧 $V_{r}$ (p.u.) の制約冕脱量 $\rho_{r i}(\%)$ と送配電系統の電力損失 $p_{i}\left(\mathrm{p} . \mathrm{u}\right.$.) からなる次式に示す評価関数 $J_{i}$ の逆数とする。

$$
J_{i}=W \Sigma\left(\rho_{r i}\right)^{2}+p_{i}
$$

$$
\text { ただし，W: } V_{r} \text { の制約逸脱に対する重み }
$$

なお，本論文では，Vrの制約逸脱が生じたときWを 非常に大きなものとして取り扱い, GAの個体として採用 しない。

（3）初期生物集団の発生 乱数(乱数は一様乱数で 以下同様)を用いて, $I(0)$ のうち $m_{1}$ 個の部分遺伝子を選 択し $(1)$ と同椂に各可変範囲で值を与え, 個体 $I_{i}$ を作る。 そして， $I_{i}$ に対して $(2)$ に基づき $f\left(I_{i}\right)$ を計算し， $V_{r}$ の すべてが電圧の上下限制約を満足するとき, 初期生物集団 の $I_{i}$ として採用する。ここでは個体数を 20 個とする。

(4) 適応度の順位付け $f\left(I_{i}\right)$ を大きい順に並べる。

（5）淘汰の実行 $f\left(I_{i}\right)$ の下位 $40 \%$ 淘汰する。

(6) 交差と増殖の実行 個体の選択確率を $f\left(I_{i}\right)$ の 大きさによって割り当てるルーレットを構成し, 乱数を用 いて親 $A, B$ を選択する。親 $A, B$ を図 1 のように各々 リング状に変形し, 乱数を用いて $m_{1}$ 個の部分遺伝子を選 択し, 選択された $A, B$ の各 $C_{j}, n_{k}$ に対応する部分遺 伝子が一つでも異なっていれば対応するそれらに対し交差 を実行する。そして, $f\left(I_{i}\right)$ を求め, $V_{r}$ の上下限制約を満 足するとき新たな子孫の遺伝子の並びを生成し，(5)で淘 汰した下位の部分に増殖する。もし, 選択された $m_{1}$ 個の
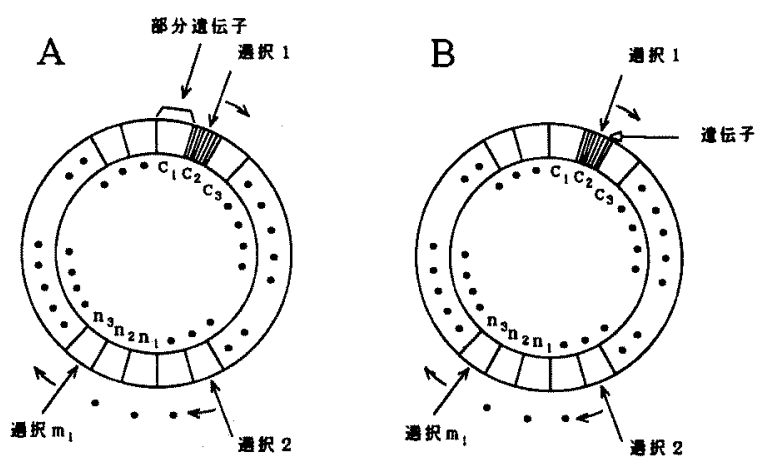

図 1 交差のための部分遺伝子の選択

Fig. 1. Selection of partial gene for crossover. 


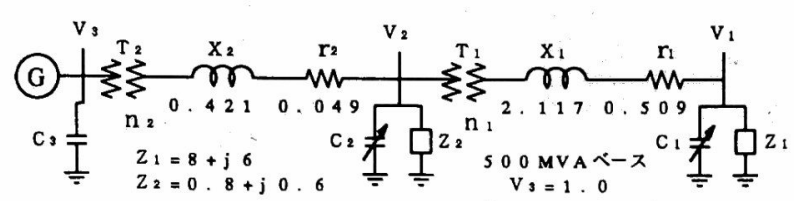

図 2 送電系統モデル

Fig. 2. Transmission system model.

$A, B$ の各対応する部分遺伝子がすべて等しい場合, 図 1 に示すように時計方向にすべての選択を一つ移動し, 異 なったものが一つでもあればこの交差と増殖を実行する。 これを繰り返しても異なるものがなければ交差は行わな い。以下，同様にこの交差による増殖を繰り返し，（5)で 淘汰した個体部分をすべて増殖する。

（7）突然変異の実行突然変異では, 突然変異率を 考慮し一点突然変異を行い, 遺伝子に相当するビットを 0 を 1 に，1を 0 にして探索可能な空間を広げる。ただし， 突然変異を実行した個体において，（2）に従い適応度を求 め, $V_{r}$ の上下限制約を満足しないとき, その個体に対す る突然変異を実行しない。

（8）生物集団の評価 生成された次世代の生物集団 の適応度が, その集団の最大適応度と 9 割以上一致した場 合, 極大值に達したと判断し, 本 GA の操作を終了する。 これを満足しないとき $(4)$ に戻る。

本 GA の初期生物集団と各世代の交差による増殖扝よ び突然変異において, $C_{j}, n_{k}$ の設定值変更を記録し, 次 の基準に基づき $C_{j}, n_{k}$ の設定值切換手順として用いる。

（i ）最適值に到達した個体のうち, $C_{j}, n_{k}$ の切換回 数が最も少ない個体を選定する。

（ii）（i ）で選定された個体中，切換えの早期に適応度 の改善度合が高い個体を選定する。

ただし，切換回数は同一の $C_{j}, n_{k}$ の值を連続的に変更 する場合を含め, 1 回としてカウントするものとする。

\section{3. シミュレーション実験結果と検討}

図 2 は, 調整パラメータである各 2 台の $C_{1}, C_{2}$ と $T_{1}$, $T_{2}$ の各倍率 $n_{1}, n_{2}$ を有する 1 発電所と 2 負荷母線からな る送電線路である。

図 3 は, 表 1 の運用条件を図 2 の送電系統に適用し, $m_{1}=1$ の本手法を行った結果で, 最終個体中第 2 章の (i )，（ii）を満足した個体の世代(交差および突然変異の 回数) に対する調整パラメータの切換えと収束状況を示 す。矢印は対応する綐軸の調整パラメータの切換えが始 まる時点を表示し, 括弧内は次の切換えの前または本 GA の終了時に定まった調整パラメータの值と, そのときの適 応度を示している。調整パラメータの切換えとともに適応 度が上昇し, 8 回の切換で実運用でき, 適応度 40.67 に収 束している。本手法と比較するために, 操作可能なところ から目標值との差を縮めるように操作を行う単純な従来方 式を実施したところ，6 回の切換操作で適応度 35.12 に収 束し，よりよい適応度に改善することができなくなる。な お, 図 3 の適応度の最大值 40.67 は切換手順を無視した場

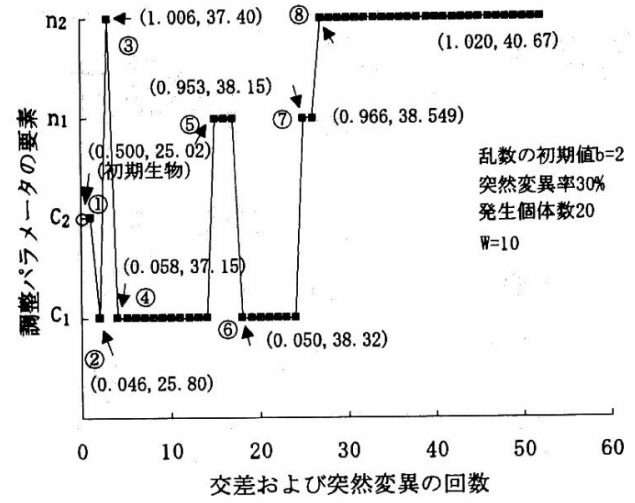

図 3 切換手順

Fig. 3. Changing process.

表 1 運用条件

Table. 1. Operational condition.

\begin{tabular}{|c|c|c|c|c|}
\hline \multicolumn{2}{|c|}{ 電圧の制約条件 } & \multicolumn{2}{|c|}{ 初期運転状態 } & \multirow{2}{*}{$\begin{array}{l}\text { 可変領域 } \\
0 \sim 0.0586 \\
\end{array}$} \\
\hline$V_{1 \max }$ & 1.1 & $\mathrm{C}_{1}$ & 0.00 & \\
\hline$V_{\lim i n}$ & 0.9 & $\mathrm{C}_{2}$ & 0.00 & $0 \sim 0.5770$ \\
\hline$V_{2 \max }$ & 1.1 & $\mathrm{n}_{1}$ & 0.90 & $0.9 \sim 1.1$ \\
\hline$V_{2 m i n}$ & 0.9 & $\mathrm{n}_{2}$ & 0.90 & $0.9 \sim 1.1$ \\
\hline
\end{tabular}

当り的な方法で求めた最大適応度 42.14 に対しても, 遜色 のない値を示している。

\section{4. まと め}

送配電系統の電力損失軽減対策手法として, 同時刻にお いて機器 1 台しか切り換えられないという条件を考慮して 本 GA を実行した。そして, 求められた最終生物集団か ら最適值に到達した個体のうち, 切換回数が少なく, 切換 えの早期に適応度の改善度合が高い個体の世代の動きを切 換手順として用いる手法を提案し, 最も簡単なモデルを用 い，本手法の有効性を明らかにした。

今後の研究としては本 GA の収束性の改善, 実系統に 近い放射状モデルやループ状モデルへの適用が考えられる。 (平成 6 年 9 月 16 日受付)

$$
\text { 文献 }
$$

（1）伊庭:「遺伝アルゴリズムに基づく無効電力最適計画」, 電学論 $\mathrm{B}, 113,865$ (平 $5-8$ )

（2）青木・山崎・水谷：「GAによる実運用を考慮した配電損失最小化 問題の解法」, 電気学会電力技術研資, PE-94-124 (平 6).

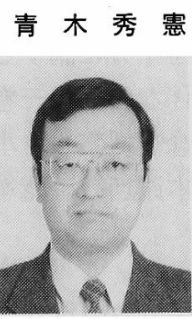

（正員） 1952 年 5 月 8 日生。1979 年 3 月東海大 学大学院修士課程修了。1987 年 4 月同大学講 師。主として。電力系統の運用と制御，ガス絶 緑・沿面放電に関する研究に従事。静電気学会会 員。

水 谷 芳 史 (正員) (電学論 B, Vol. 115, No. 3, p. 291 参照) 